\title{
生後 3 週間のヒツジ母子間における音声コミュニケーションによる 接近のイニシアチブとその変化
}

\author{
苗川博史 \\ 湘南工科大学附属高等学校, 藤沢市 $251-8511$
}

(2003. 9. 4 受付，2004. 2. 2 受理)

\begin{abstract}
要 約 14 頭もしくは20頭の小群内において, 生後3 週齢までのヒツジ母子 5 組の音声コミュ二 ケーションにおける母子間の反応（以下相互作用）を音声表記と情報量に基づいて検討し，母子間の接 近行動の経日的推移について解析した。音声表記については，調音作用の観点から口の開閉によって構 成される母ヒツジ/nnn/と/nae/と/nnae/および子ヒツジ/nnn/と/eee/と/nee/を発声タイプとして表 した。相互作用については，母子それぞれ3タイプの発声と，これらに対する反応を８タイプに分類し た 24 通りのダイアド（母子いずれかの発声とその後に続く一方または双方の行動を 1 組の完了行動と する）ならびに，それらの情報量について解析した。また，接近行動については，発声の有無に分けて 母子ペア毎に経日的に解析した。 その結果, 母子間の相互作用は, 情報伝達機能上, 口を開けた発声が 主導を占め, 発声後は相手を視認もしくは注視し，その後の行動に移行する反応系で構成されていた. その際には， ロの開閉のタイプによって生起する反応のしかたに個体差が見られ，発声のしかたによっ て応答が異なることが示された。また，いずれの発声においても母子ヒツジ間に共有される情報量は 0 ビットよりも大きく，母子ヒツジ双方に情報の共有があったことが示された。音声表記の結果について は, 発声夕イプによって周波数と持続時間に違いが認められ, それぞれの発声構造の特徵を示すことが できた。すなわち，母ヒツジの場合は，ロを開けた/nae//nnae/タイプが，ロを閉じた/nnn/タイプより も周波数が 50 ヘルツ高く, 発声時間も 0.1 秒長かった. 子ヒツジの場合は, 口を開けた/eee/と/nee/夕 イプが， ロを閉じた $/ \mathrm{nnn} /$ タイプよりも周波数が 50 ヘルツ高いものの，発声時間は $0.1 \sim 0.2$ 秒短かっ た. 発声に基づく接近のイニシアチブは, 生後 3 週齢までは母ヒツジ主導型であったが, 発声によらな い接近のイニシアチブの割合については，子ヒツジの方が大きい傾向にあった.
\end{abstract}

日本畜産学会報, 75 (2)：228-239, 2004

動物の音声いわゆる鳴き声は, 個体間のコミュニケー ションを維持する上で，重要な役割を果たし，個体間を 結びつけるための信号として使用されているものと考え られている (Collias 1956). 動物のコミュニケーション 信号は，定型的なものが多く種特異的であるといわれる (Hafez 1992)。また，その定義は，聞き手の行動に影響 を及ぼす情報を伝達することであり（Halliday と Slater 1998), 信号や応答そのものではなく, これら 2 つ関係 であり, 適応的な関係であるとされている (Wilson 1984).一般にヒツジのコミュニケーションは, 視覚, 聴 覚, 嗅覚などの感覚機能によって行われているといわれ ている (Houpt 1982). ヒツジの感覚機能のうち, 音声に よってヒツジの母子が互いをどのように認知しあうかに ついては, 聴覚機能 (Halliday と Slater 1998), 母子間の 音声機能 (Shillito ら 1972 ; Shillito と Alexander 1975; Alexander ら 1977), 母子間の視覚・聴覚認知 (Harold
1963 ; Arnold 1975 ; Poindron と Carrick 1976), 母の子 に対する識別 (Shillito と Alexander 1975; Martin と Bateson 1990）などの報告がある.

これらのヒツジの音声に関する研究の多くは, 飼育条 件や飼育方法の改善が目的亡されており（Bright 1986）, またこれらの実験は，認知刺激の人為的操作に基づいた ものが多い.しかし，特定の音を発声する舌，口唇，枵 の動きなどの調音作用（柴谷ら $1982 ;$ Kent とRead 1996)の観点から, ヒツジの音声と行動を同時に観察し, ヒツジの置かれた状態を類推していくことは，ヒツジを 日常管理していく上で役立つと考えられるが, 音声によ る母子ヒツジ間のコミュニケーションのメカニズムにつ いては，未解明な部分が多い。これまでの家畜の音声を 音節として表記する試み(Kiley 1972 ; Huletら 1976 ; Houpt 1982）は，いずれも発声個体のみの音声を表記し たものであり，最初に発声する作用個体とそれに対して

連絡者：苗川博史（fax：0467-54-5328, e-mail : naekawa@beige.plala.or.jp） 
応答する反応個体間の相互作用については論じられてい ない. 特に，母子間の相互作用を調音作用と行動型およ び伝達された情報量として解析した報告は，これまで見 られない。

本研究では，小群内における母子ヒツジ間の情報量を 母イニシアチブの音声と子の反応系, 子イニシアチブの 音声と母の反応系として分類し，これらをもとに，音声 による相互作用と母子間の接近のイニシアチブ（Martin と Bateson 1990）が, 生後 3 週齢までにどのように推移 していくかについて解析した。 また，音声によるコミュ ニケーションの基礎的知見を得るために，授乳一吸乳に 結びつく際の発声と応答の母子行動を調音作用の機能か ら音声表記（Kent とRead 1996）としてまとめた.

\section{材料および方法}

\section{1. 供試羊}

北海道登別市の $\mathrm{H}$ 牧場羊舎内で飼養されていた 5 組 のサフォーク種母子ヒツジを供試動物とした. 対象とし た 5 組の母子は, 分娩日が近い個体を羊舎内より選別し た. 母ヒツジの年齢は, 1 号, 2 号, 3 号, 4 号および 5 号 ヒツジがそれぞれ 3 歳, 5 歳, 3 歳, 2 歳, 3 歳であった. また，子ヒツジの性別および誕生時の体重は，1号，2 号, 3 号, 4 号, および 5 号ヒツジがそれぞれ雌 $5.1 \mathrm{~kg}$, 雌 $6.5 \mathrm{~kg}$, 雌 $5.6 \mathrm{~kg}$, 雄 $6.2 \mathrm{~kg}$, 雄 $4.1 \mathrm{~kg}$ であった。観察期 間中に群の再編成が 2 回（以下小群 1 2）あったが， 5 組の母子は, 常に同一の小群内で飼養されていた.

\section{2. 飼養管理}

管理者は, 1 日 1 回午前中にサイレージと乳用牛配合 飼料を, 午後には乾燥ワラをそれぞれ慣例に従い給与し た。舎内には, 飲水場が設置されており, ヒツジは自由 に飲水できた。供試母子ヒツジは, 分娩後 1 3 日に分娩 柵 $\left(10.08 \mathrm{~m}^{2}\right)$ から小群 $1\left(58.32 \mathrm{~m}^{2}\right)$ に管理者によって移 動され, 移動後 3 日目からは小群 $2\left(174.96 \mathrm{~m}^{2}\right)$ で飼養さ れた. 小群 1 は, 供試母子ヒツジを含めた母子群 (単子) 14 頭, 小群 2 は同じく 20 頭でそれぞれ構成されていた.

\section{3. 行動観察}

観察者は，小群内の個体が見渡せる1箇所に位置し， 録音機材（カセットテープデッキ:ソニーカセットデン スケ TC-2890SD, 外部マイクロホン: ソニーECM150, ローノイズテープ: C-60, ソニー, 東京) とカメラを併 用して，供試母子ヒツジの音声とその前後の行動を記録 した. 録音機材への録音の際は, 発声と同時に発声個体 とその行動を観察者が口頭で記録した. 記録は，母子間 の発声頻度が集中する給餌前後の時間帯を中心に 1 日平 均 8 時間, 合計 160 時間, 供試母子ヒツジを生後 1 日齢 から 3 週齢まで, 羊舎内の分婏柵内, 小群 1 内, 小群 2 内で実施した。

\section{4. 行動解析}

観察中に発せられた供試母子ヒツジにおける音声およ
び行動を記録テープから拾い上げ，これらを供試母子， 日齢ごとに，発声によるものとよらないものに分類し デー夕を解析した，発声によるものについては，母子双 方の音声とその後の行動を 1 組の完了行動として, 発声 によらないものについては母子の遭遇から分離するまで の行動を1組の完了行動としてそれぞれ解析し, 相互作 用ならびに接近のイニシアチブとその変化について検討 した。

\section{5. 母子間の相互作用の解析}

音声コミュニケーションによる母子間の相互作用の解 析については，情報理論に基づく個体間相互作用の解析 方法（粕谷と藤田 1984）に従った. 母子間の音声による 相互作用は，母または子ヒツジがイニシアチブを有した 音声（作用個体，以下S）とそれに反応した母または子 ヒツジ（反応個体，以下R）をダイアド（母子いずれかの 音声とその後に続く一方または双方の行動を 1 組の完了 行動とする）として算出した. 発声時の口の開閉状態お よび発声後の反応個体の行動から, 音声表記は S を後述 の 3 タイプ, Rを後述の 8 タイプに分類し, 合計 24 通り の組み合わせに分類してマトリクスを作成し相互作用を 解析した.

ダイアドによって作成したマトリクス Sの3タイプ は, 行動観察から口を閉じた発声の場合を, 国際音声字 母 (IPA) の表記（Kent とRead 1996）に基づいて，まず 口を閉じた発声を子音の音素の/n/を組み合わせた音 節/nnn/ (鼻音で調音点が軟口蓋) タイプとして表した. 次に， 口を閉じた状態から開けたときの発声の場合を， 子音 $/ \mathrm{h} / \mathrm{g}$ 母音/a/および/e/の音素の組み合わせた音節 として母ヒツジの/nae/と/nnae/（喉音で前舌を使用し た低母音) タイプ および子ヒツジの/eee/と/nee/(喉 音で前舌を使用した中母音）タイプとして表した，Rの タイプは, 上記 S と同じ発声の 3 タイプに加えて, 発声 なしを5タイプに分類した. 5 タイプは，Sの発声後に (1)RからSを視認または注視した場合（以下A1)，(2)R からSに接近した場合 (以下A2), (3)RからSに接近し た後, 授乳もしくは吸乳した場合 (以下 $A 3$ ), (4) S から Rに接近した場合 (以下B1), (5) S からRに接近した後, 授乳もしくは吸乳した場合（B2）として表した.

解析項目は, 各組の $S$ の情報量 (発声前に比べ発声後 ではどれだけの情報量が得られるかの値, 以下 $\mathrm{H}(\mathrm{S})$ ), $\mathrm{R}$ の情報量（反応が起こる前に比べ，起こった後ではど れだけの情報量が得られるかを示す値, 以下 $H(R)), S$ の情報量の最大値（以下 $\operatorname{Hmax}(\mathrm{S})$ )，R の情報量の最大 値 (以下 Hmax (R)), ダイアドの情報量 ( $\mathrm{S}$ とRが共有 する情報量の和, 以下 $\mathrm{H}(\mathrm{S}, \mathrm{R})$ ), $\mathrm{S}$ とRに共有（伝達） される情報量 (以下 $\mathrm{T}(\mathrm{S}, \mathrm{R})$ ), 情報伝達の効率 ( $\mathrm{S}$ もし くはRの情報量のうちどれだけの割合が伝達されてい るか, もしくは使用されているかを示す, 以下 TE）とし た.ここでのH（S) は, $\log _{2} N-(1 / N) \sum_{i=1}^{m}$ fi. ・ $\log _{2}$ fi. (f. 
は, $R$ 行の合計, $\mathrm{m}$ は $\mathrm{S}$ の種類， $\mathrm{N}$ は $\mathrm{S}$ に対する $\mathrm{R}$ の合 計), $H(R)$ は $\log _{2} N-(1 / N) \cdot \sum_{i=1}^{n}$ f fi $\log _{2} \cdot f(. f$ は, $S$ 列の合計, $\mathrm{n}$ はRの種類, $\mathrm{N}$ は $\mathrm{S}$ (対するRの合計), $\mathrm{H}$ (S, R) は, $\log _{2} N-(1 / N) \cdot \sum_{i=1}^{m} \sum_{j=1}^{n}\left(\mathrm{fij} \cdot \log _{2} \mathrm{fij}\right), \mathrm{T}(\mathrm{S}, \mathrm{R})$ はH $(S)+H(R)-H(S, R), T E$ は $(S, R) / H(S)$ および $T(S, R) / H(R)$ でそれぞれ算出した（粕谷と藤 $\boxplus$ 1984).

母子間の相互作用の統計処理は, ダイアドの組み合わ せによる割合はアークサイン変換後に，また情報量は $\chi^{2}$ 検定によりそれぞれ行った. ヒツジ母子間のロを閉じた 発声/nnn/タイプならびにロを開けた発声/nae/と /nnae/または/eee/と/nee/タイプとSおよびRの発声 の有無との関連については, $2 \times 2$ の分割表にまとめ, こ れをもとにFisher の正確確率検定法により統計検定し た. 母子ヒツジに共有される情報量 T $(S, R)$ が有意に0 より大きいか, また母および子ヒツジの情報量 H (S) お よび H (R) が情報量の最大值 Hmax より有意に小さい かの検定には, Millerの $\chi^{2}$ 検定を用いた.

また発声のホルマント構造の特徴を 2 号母子ヒツジに おけるイニシアチブ個体の音声表記を一例として, 母ヒ ツジ/nnn/と/nae/と/nnae/および子ヒツジ/nnn/と /eee/と/nee/に分け, ソナグラム（SG-04, リオン, 東 京)によりそれぞれ比較した。

6. 母子間の接近行動におけるイニシアチブのとり方 母子間の接近行動の持続に対する母ヒツジの寄与の指 数,つまり接近のイニシアチブ (Martin と Bateson 1990)については, UE/ (UE+UL) -SE/ (SE+SL)の 式で算出した。ここでのUEは，母ヒツジの音声により 母子ヒツジが一緒になった回数, UL は子ヒツジの音声 により母子ヒツジが一緒になった回数, SE は母ヒツジ の音声により母子ヒツジが離れた回数, SL は子ヒツジ の音声により母子ヒツジが離れた回数とした. 母子の接 近のイニシアチブについては，供試母子ヒツジが小群 1 に導入された日から 3 週齢時までについて算出し, 発声 によるものと発声によらないものとに分別してまとめ た. 供試母子ヒツジ間の接近のイニシアチブに経日的変 化があるか否かの検定には, 最小自乗法による重複測定 分散分析を用いた。

\section{結果}

\section{1. 母ヒツジのイニシアチブによる音声の作用}

母ヒツジのイニシアチブによる発声とそれに対する子 ヒツジの反応の音声表記タイプを図 1-Aに，またこれら の割合を表 1 に示した. 母ヒツジがイニシアチブを有し た発声回数は, それぞれ 168 回, 150 回, 130 回, 89 回と 5 号, 3 号, 4 号, 2 号ヒツジの順に多く, 1 号ヒツジにつ いては22回と少なかった。ロを開いた状態での発声は, 1 号, 2 号, 3 号, 4 号および 5 号ヒツジがそれぞれ 77\%, 36\%，95\%，79\%，92\%であり，口を閉じた発声よりも
多い傾向にあった。この中で， ロを開いた発声タイプ別 の比率は/nae/ :/nnae/ : ロを閉じた/nnn/が 2: 1: 1 で構成されていた。母ヒツジに対する子ヒツジの反応系 は, A1 夕イプ (母ヒツジの発声後, 母ヒツジが子ヒツジ を注視もしくは視認したのみ）がもっとも多く，1号，2 号，3号，4号および 5 号ヒツジはそれぞれ 59\%, 47\%, 72\%，55\%，63\%であった.ダイアドの組み合わせでは， 1 号, 3 号および 5 号ヒツジが発声/nae/とA1 の反応の 組み合わせがもつとも多く占め，それぞれ 32\%，59\%， $56 \%$ であった. 2 号ヒツジは, 発声/nnn/とA1の反応の 組み合わせが $29 \% ， 4$ 号ヒツジは，発声/nnae/とA1の 反応の組み合わせが $22 \%$ もっとも多く占めた. 母ヒ ツジの発声後, 子ヒツジに対する授乳行動に結びついた のは平均 4\% であり，その内訳は， ロを開けた発声 /nae/タイプ:/nnae/タイプ: ロを閉じた/nnn/が $9: 4$ : 5 で構成されていた。 子ヒツジから母ヒツジに対する 吸乳行動に結びついたのは平均 $9 \%$ であり，その内訳 は, 口を開けた発声/nae/タイプ:/nnae/タイプ: $\square を$ 閉じた/nnn/が5:3:1で構成されていた.また，母ヒツ ジの発声と子ヒツジに応答のあった組み合わせにおけ る母ヒツジの発声タイプ別の比率は/nnn/: / nae / : /nnae/が 2: 2:1であった（表 1). ロの開閉のタイプに よって生起される反応のしかたには，2 号個体に有意差 が認められ，母ヒツジの発声タイプによって子ヒツジの 応答が有意に異なっていた（Fisher の正確確率検定法， $\mathrm{P}<0.05)$.

母ヒツジがイニシアチブをとった場合の情報量 H (S) は， 2 号ヒツジ (4.971 ビット) を除き，子ヒツジにおけ る情報量が母ヒツジの情報量よりも大きい傾向を示し， 信号の情報量のうち反応個体において使用される情報量 の割合が多いことが示唆された (表 2). また母子ヒツジ に共有される情報量 $T(S, R)$ は， 2 号ヒツジが 3.828 ビットで $1 \%$ 水準のときの $\chi^{2}$ 値よりも有意に大きかっ た $(P<0.001)$. いずれの個体も，母子間に共有される情 報量は０ビットよりも大きく，母子ヒツジの双方には情 報の共有があったことが示唆された。

図 2 に 2 号母ヒツジがイニシアチブを有した/nnn/ と/nae/と/nnae/のスペクトログラフの一例を示し た./nnn/タイプは周波数が 150 ヘルツで，ホルマント 構造が不明瞭であり，持続時間は 0.60 秒であった。ま た／nae/および/nnae/タイプは, 周波数が 120 ヘルツ で，ホルマント構造が明瞭で，持続時間は $0.71 〜 0.89$ 秒 であり, 調音作用による発声構造の違いが示唆された。

\section{2. 子ヒツジのイニシアチブによる音声の相互作用}

子ヒツジのイニシアチブと母ヒツジの反応系による音 声表記のタイプを図 1-Bに，また母子間の相互作用によ る組み合わせを表 3 にそれぞれ示した。子ヒツジがイ二 シアチブを有した発声回数は，2 号，1号，4号の順に多 く，それぞれ 61 回，21回，16回であり，3号は 5 回，5 


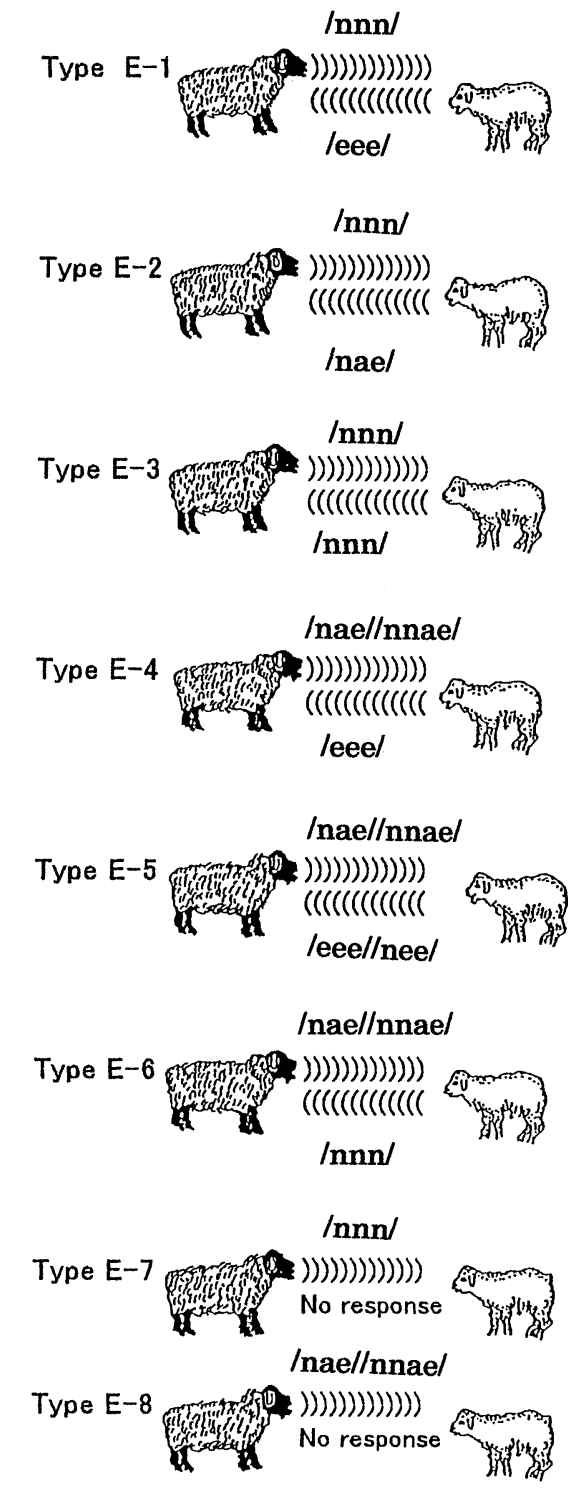

A. Vocalization of ewe initiative

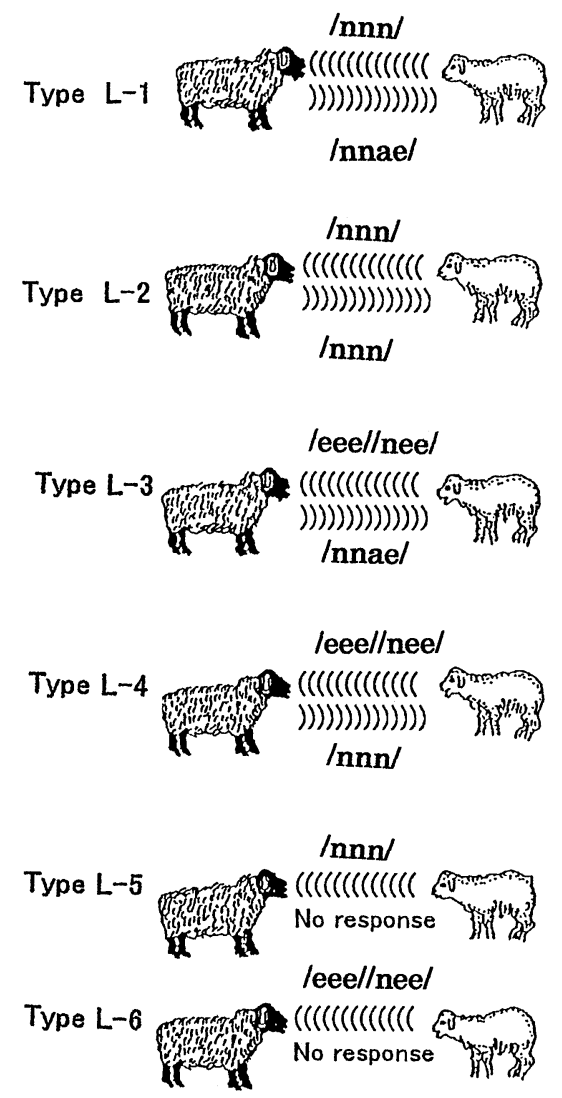

B. Vocalization of lamb initiative

Fig. 1. Phonetic notation of vocalization in ewe and lamb.

/nnn/ : closed mouth, /nae//eee/ : open mouth, /nnae//nee/ : open mouth from closed mouth.

Type E-7, E-8 : Ewe approching lamb before smelling, protecting, eye contact and nursing.

Type L-5, L-6 : Lamb approching ewe before suckling, leading and following.

Ewe initiated vocalization include 8 types and lamb initiated vocalization include 6 types.

号は 6 回であった。以下の解析は, 発声回数の少なかっ た 3 号，5号ヒツジを除いて，1号，2号，4号ヒツジを 対象に行った. 口を開いた状態での発声は, 1 号, 2 号お よび 4 号ヒツジがそれぞれ 62\%，82\%，56\%であった。 この中で，口を開いた状態での発声タイプ別の比率は, /eee/:/nee/:/nnn/が1:6:3であった. 子ヒツジの 発声に対する母ヒツジの反応系は, A1タイプがもっと も多く，1号，2号および4 号ヒツジがそれぞれ 57\%， 51\%，31\%であった. 行動分類の組み合わせでは，1号，
2 号, 4 号ヒツジ共に/nnae/とA1 タイプの組み合わせ がもっとも多く占め, それぞれ 33\%，43\%，31\%であっ た. 子ヒツジの発声後, 吸乳行動に結びついたのは 1 号, 2 号および 4 号がそれぞれ 14\%，10\%，19\%であった。

そのうち，ロを開けた状態の発声/eee/タイプが1号, 2 号および 4 号ヒツジが 0\%, 2\%, 0\%であり,/nee/タイ プは 1 号，2号，4号ヒツジがそれぞれ 5\%，7\%，6\%で あった. ロを閉じた状態での発声, /nnn/タイプは 1 号, 2 号，4号ヒツジが 10\%，2\%，13\%であった. A2 タイプ 
Table 1. Vocal interaction initiated by the ewe

\begin{tabular}{|c|c|c|c|c|c|c|c|c|c|c|c|}
\hline & & \multirow[b]{2}{*}{ Type } & \multirow[b]{2}{*}{ /nnn/ } & \multirow[b]{2}{*}{ /eee/ } & \multirow[b]{2}{*}{ /nee/ } & \multicolumn{5}{|c|}{ Lamb } & \multirow[b]{2}{*}{ Total } \\
\hline & & & & & & A1 & $\mathrm{A} 2$ & A3 & B1 & B2 & \\
\hline & No 1 & /nnn/ & 0 & 0 & 0 & 22.7 & 0 & 0 & 0 & 0 & 22.7 \\
\hline & & /nae/ & 13.6 & 0 & 0 & 31.8 & 13.6 & 0 & 0 & 4.6 & 63.6 \\
\hline & & /nnae/ & 0 & 4.6 & 0 & 4.6 & 0 & 0 & 0 & 4.6 & 13.8 \\
\hline & & Total & 13.6 & 4.6 & 0 & 59.1 & 13.6 & 0 & 0 & 9.1 & 100 \\
\hline & No $2^{*}$ & /nnn/ & 10.1 & 1.1 & 12.4 & 29.2 & 4.5 & 3.4 & 1.1 & 2.3 & 64.1 \\
\hline & & /nae/ & 1.1 & 0 & 2.3 & 8.9 & 4.5 & 0 & 0 & 2.3 & 19.1 \\
\hline & & /nnae/ & 3.4 & 2.3 & 0 & 8.9 & 1.1 & 1.1 & 0 & 0 & 16.8 \\
\hline & & Total & 14.6 & 3.4 & 14.7 & 47.0 & 10.1 & 4.5 & 1.1 & 4.6 & 100 \\
\hline \multirow[t]{12}{*}{ Ewe } & No 3 & /nnn/ & 0 & 1.3 & 0 & 3.3 & 0 & 0 & 0 & 0 & 4.6 \\
\hline & & /nae/ & 0.7 & 2.7 & 2.0 & 59.3 & 8.0 & 2.7 & 1.3 & 2 & 78.7 \\
\hline & & /nnae/ & 0.7 & 0 & 0.7 & 9.3 & 3.3 & 0 & 0 & 2.7 & 16.7 \\
\hline & & Total & 1.4 & 4 & 2.7 & 71.9 & 4.1 & 2.7 & 1.3 & 2.9 & 100 \\
\hline & No 4 & /nnn/ & 0 & 0 & 0.8 & 13.8 & 2.3 & 1.5 & 0.8 & 1.5 & 20.7 \\
\hline & & /nae/ & 0.8 & 0.8 & 1.5 & 20.0 & 10.8 & 1.5 & 0.8 & 3.1 & 39.3 \\
\hline & & /nnae/ & 0 & 0.8 & 0 & 21.5 & 8.5 & 1.5 & 0.8 & 6.9 & 40.0 \\
\hline & & Total & 0.8 & 1.6 & 2.3 & 55.3 & 21.6 & 4.5 & 2.4 & 11.5 & 100 \\
\hline & No 5 & /nnn/ & 0.5 & 0 & 1.8 & 1.8 & 1.2 & 0.5 & 0 & 1.8 & 7.6 \\
\hline & & /nae/ & 1.8 & 0.5 & 0 & 56 & 6.0 & 4.8 & 2.4 & 11.3 & 82.8 \\
\hline & & /nnae/ & 0 & 0 & 0 & 5.4 & 1.2 & 1.2 & 0 & 1.8 & 9.6 \\
\hline & & Total & 2.3 & 0.5 & 1.8 & 63.2 & 8.4 & 6.5 & 2.4 & 14.9 & 100 \\
\hline
\end{tabular}

Unit : (\%) Sample number : Ewe (Lamb) No $1: 22$ (21), No $2: 89$ (61), No $3: 150$ (5), No $4: 130$ (16), No 5 : 168 (6). /nnn/ : closed mouth, /nae/, /eee/ : open mouth, /nnae/, /nee/ : open mouth from closed mouth.

A1 : No response. Eye contact from ewe. A2 : No response. Ewe approaching lamb.

A3 : No response. Ewe approaching lamb before nursing.

B1: No response. Lamb approaching ewe. B2 : No response. Lamb approaching ewe before suckling.

* Fisher's exact probability test, $\mathrm{P}<0.05$.

（発声後に子ヒツジから母ヒツジに接近行動のみ示した 割合）は，2 号ヒツジの $10 \%$ に見られるのみであった。 子ヒツジの発声に対するB2 タイプ（母ヒツジの音声に よる反応なし.母ヒツジから子ヒツジに接近. その後に 授乳行動）の組み合わせは見られなかった. 口の開閉に よって, 子ヒツジの発声に対する母ヒツジの応答が異な ることが示された（表 3). ダイアドの組み合わせの中で は，子ヒツジの発声タイプに対する母ヒツジの反応にお いて，2 号個体が他個体と有意に異なっていた（Fisher の正確確率検定法, $\mathrm{P}<0.05)$.

子ヒツジがイニシアチブを有した時の情報量 H（S） については，1号，3号，5号子ヒツジにおいて母ヒツジ よりも大きかった (表 2). ダイアドの情報量 H (S, R) については，1 号子ヒツジにおいて 2.934 ビットであり, 使用される情報量の割合が多いことを示した。母子間に 共有される情報量は，2 号ヒツジにおいて他母子よりも 有意に多く $(P<0.001)$, また, いずれの個体も0ビット
より大きく，母子双方には情報の共有があったことが示 された.

図 3 に，2 号子ヒツジがイニシアチブを有した/nnn/ と/eee/と/nee/のスペクトログラフの一例を示した. /nnn/タイプは，周波数が 250 ヘルツで， ホルマント構 造が不明瞭であり，持続時間が 0.75 秒であった。 また， / eee/と/nee/タイプは持続時間が 0.60〜0.66 秒であり, 母ヒツジ（図 2）とは異なった調音作用による発声構造 の特徵を有していることが示唆された。

\section{3. 接近行動のイニシアチブ}

母子ヒツジ 5 組の発声の有無による接近行動のイニシ アチブの割合を経日的に表 4 に示した。表中の数值は 1 ならば $100 \%$ 母主導になり，-1ならば 100\% 子主導に なることを示している。したがって, 発声があった場合 の接近行動のイニシアチブについては, 平均（土標準偏 差) で $0.55 \pm 0.45 \sim 0.81 \pm 0.35$ と生後 21 日目までは, 母 ヒツジ主導型の傾向が見られた。また，接近行動のイ二 
苗川

Table 2. Information quantity of diad between ewe and lamb

\begin{tabular}{|c|c|c|c|c|c|c|c|c|c|c|}
\hline \multirow[b]{2}{*}{ Item/No } & \multicolumn{5}{|c|}{ Ewe initiative } & \multicolumn{5}{|c|}{ Lamb initiative } \\
\hline & 1 & 2 & 3 & 4 & 5 & 1 & 2 & 3 & 4 & 5 \\
\hline$H(S)$ & $1.293^{*}$ & 4.971 & $0.909 * * *$ & $1.529 * *$ & $0.835^{* * *}$ & 1.418 & $1^{* * *}$ & 1.522 & 1.272 & 1.842 \\
\hline$H(R)$ & $1.749 * * *$ & $2.296^{* * *}$ & $1.544^{* * *}$ & $1.911^{* * *}$ & $1.789 * * *$ & 1.812 & $1.817^{* *}$ & 1.322 & 2.18 & 1.842 \\
\hline $\operatorname{Hmax}(\mathrm{S})$ & 1.585 & 1.585 & 1.585 & 1.585 & 1.585 & 1.585 & 1.585 & 1.585 & 1.585 & 0 \\
\hline $\operatorname{Hmax}(\mathrm{R})$ & 2.3 & 3 & 3 & 3 & 3 & 2.322 & 2 & 1 & 2.322 & 1.585 \\
\hline$H(S, R)$ & $2.606^{* * *}$ & $2.439 * * *$ & $2.339 * * *$ & $2.372^{* * *}$ & $2.511^{* * *}$ & 2.934 & $2.519 * * *$ & 2.322 & 2.774 & 1.842 \\
\hline$T(S, R)$ & 0.436 & $3.828^{* * *}$ & 0.114 & 0.068 & 0.113 & 0.296 & $0.298^{* * *}$ & 0.522 & 0.678 & 1.842 \\
\hline $\mathrm{TE}(\mathrm{S})$ & 0.337 & 0.77 & 0.125 & 0.044 & 0.135 & 0.209 & 0.298 & 0.129 & 0.533 & 0.832 \\
\hline $\mathrm{TE}(\mathrm{R})$ & 0.249 & 1.667 & 0.074 & 0.036 & 0.063 & 0.163 & 0.164 & 0.159 & 0.311 & 0.749 \\
\hline
\end{tabular}

Unit : (bit) Sample number : Ewe (Lamb) No 1:22 (21), No $2: 89$ (61), No $3: 150$ (5), No 4: 130 (16), No $5: 168$ (6). $H(S)$ : Information of action, $H(R)$ : Information of receiver,

Hmax (S) : Maximum Information of action, Hmax (R) : Maximum Information of the receiver,

$H(S, R)$ : Information of diad, $T(S, R)$ : Information of communication by action and the receiver,

TE (S) : Efficiency of information of action ewe and lamb, TE (R) : Efficiency of information of the receiver,

$H(S)$ and $H(R)$ significantly differ and are lower than $H \max (S)$ and $H \max (R)$ (Miller's $\chi^{2}$ test, ${ }^{*} P<0.05$, ${ }^{*} P<$ $\left.0.01,{ }^{* * *} \mathrm{P}<0.001\right)$.

$H(S, R)$ Indicates significant difference between $\chi^{2}$ value at $1 \%$ level.

$T(S, R)$ differs significantry differs and greater than 0 bit (Miller's $\chi^{2}$ test, ${ }^{* *} \mathrm{P}<0.01,{ }^{* * *} \mathrm{P}<0.001$ ).

シアチブには， 1 号と 5 号母ヒツジ間に有意差がみられ た (重複測定分散分析, $P<0.05$ ). 発声がなかった場合 の接近行動のイニシアチブは, 2 号, 5 号の子ヒツジは生 後 5 日目から, 3 号子ヒツジは 7 日目から, 4 号子ヒツジ は8日目から, 1号子ヒツジは10日目からそれぞれ出現 した. 発声がなかった場合の接近行動のイニシアチブの 割合は，生後 21 日目まで，2号，3号子ヒツジを除き， 子ヒツジの方が母ヒツジよりも大きい傾向にあった.

\section{考察}

今回観察した羊舎内における生後 3 週間の母子間の音 声をともなうコミュニケーションについては，母子ヒツ ジ共に，口の開いた状態が多く見られ，発声後は母また は子ヒツジに対して注視もしくは視認行動をとってい た. 母ヒツジの発声後の子ヒツジの反応および子ヒツジ の反応に対する母ヒツジの反応は，相手を注視・視認す るが約 6 割であり，接近して授乳または吸乳に結びつい た行動がそれぞれ約 2 割ずつで構成されることがわかっ た.このことは，発声個体に対する反応個体に応答なし が見られた場合の発声個体の行動は，相手を注視もしく は視認しただけであり，必ずしも授乳や吸乳行動に結び つかなかったことを意味している。この結果は，母ヒツ ジは子ヒツジに対して注意をひきつけられること，その 誘引作用は子ヒツジのほうが母ヒツジよりも強いが，母 ヒツジにとってわが子の声を受け入れるために聴くこと は絶対的なものではないとする報告（Huletら 1976）に
合致している.

また Shillito（1972）は，ヒツジ母子間の音声をロの開 閉による 2 つ基本型に大別する中で。ロを開けた状態 での発声は，母子双方が互いに離れているときや緊張を 強いられたときにみられ，援助を求めたり，不安を表す ものと解釈している。一方，口を閉じた状態での発声は， 母子双方が近くにいるときや母ヒツジが警戒や危険を感 じ取るなどの軽い緊張状態を表す発声と解釈されてい る.ウシの音声を研究したHoupt (1982) は，口を閉じた 状態での夕イプの低い発声音は，新生子牛を世話する母 ウシが発することを報告しており，今回の口の開閉によ る母ヒツジの発声も上記の報告と同じ機能をもつものと 考えられた. 出生後 4 週齢までのヒツジ母子間における 行動関係を調べた Morgan と Arnold (1974) の報告では, 観察例の $56 \%$ では母子間距離が $10 \mathrm{~m}$ 以内に維持され, 音声と行動間には，有意な相関があったことを報告して いる. 子ヒツジが生後, 初めて耳にするのは周波数の低 い，喉を鳴らすような母ヒツジの音声で，この音声は， 自然界では遠くまで聞こえず，捕食者にさとられず安心 して母と子が交わすことの出来る適応上の機能を含んで いると考えられる (Bright 1986).

子ヒツジは，生後 2〜3 日経過すると自分の母ヒツジ を識別するために視覚的および聴覚的な手がかりを使用 し始め，また，多くの子ヒツジは母ヒツジの音声を識別 することが出来, この識別能力は, 生後約 4 週齢時まで の間, 成長と共に発達していくとされている (Shillito と 

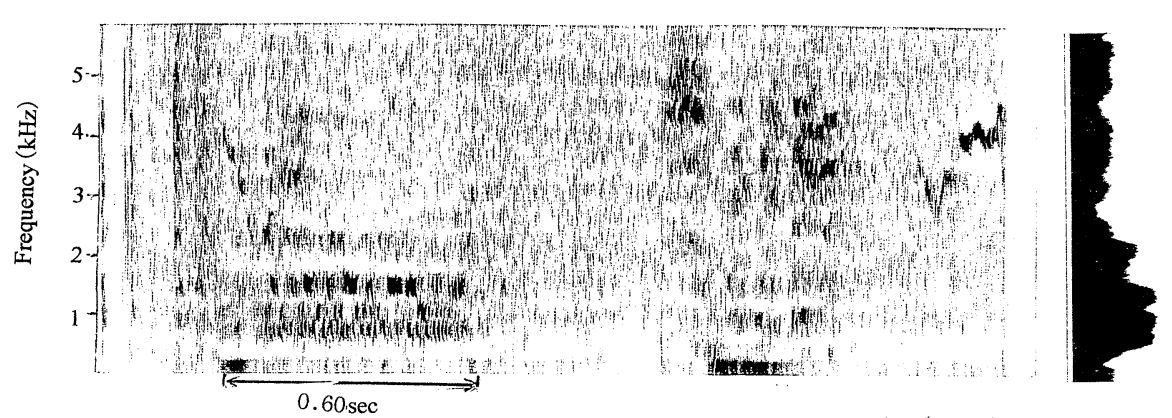

/nnn/

Time $(2.4 \mathrm{sec})$

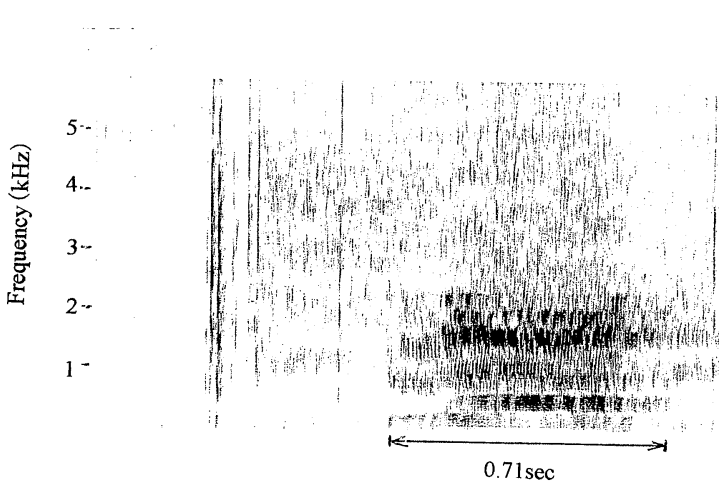

$71 \mathrm{sec}$

/nael

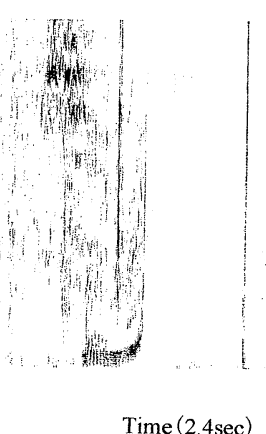

Time $(2.4 \mathrm{sec})$
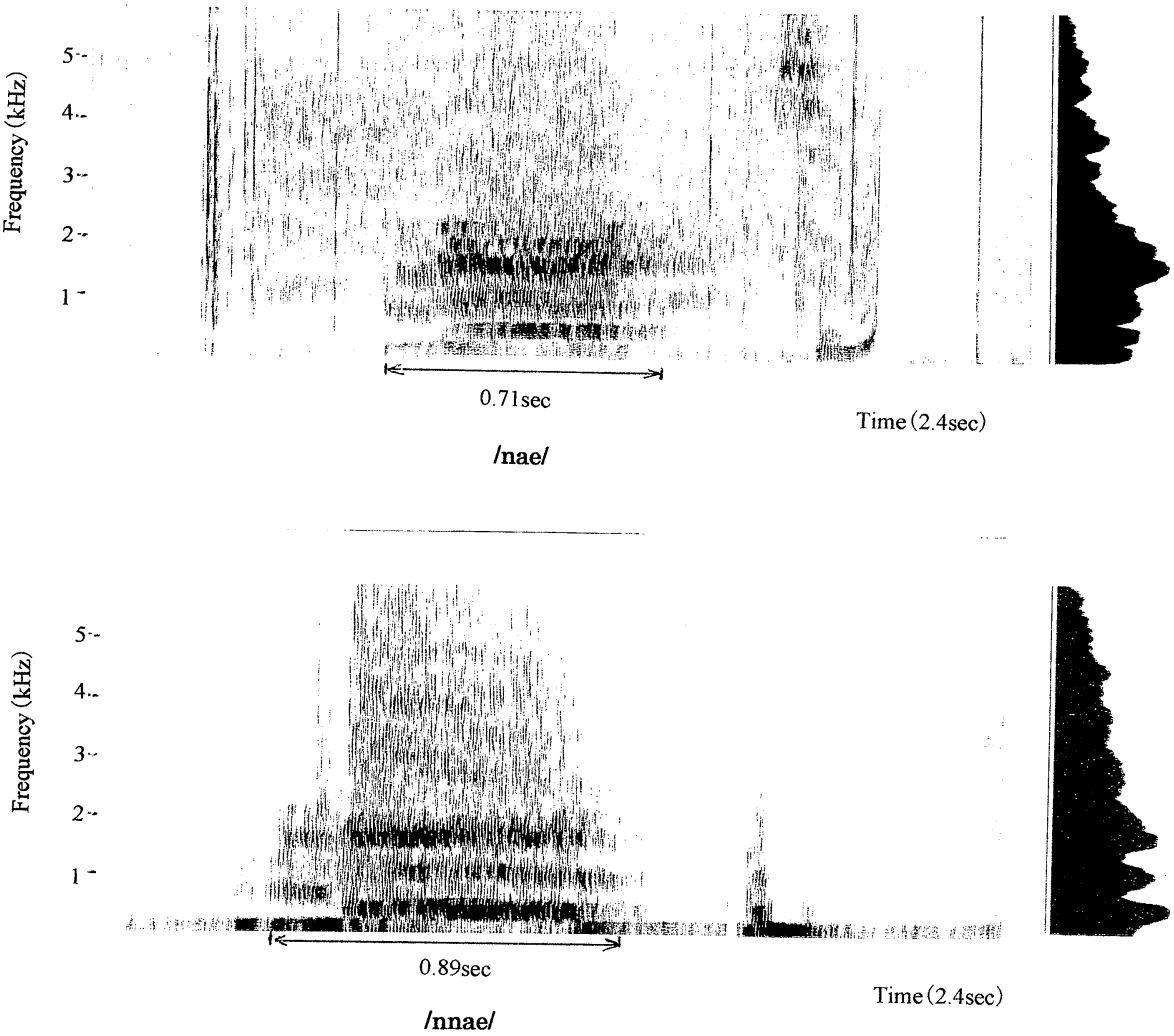

Fig. 2. Spectrogram of vocalization /nnn/, /nae/, /nnae/ of ewe No. 2 initiative and section analysis (wide-band filter).

Alexander 1975).とくに視覚的な手がかりは，母ヒツジ が接近してくる他の子ヒツジを識別するのに重要なもの となる（Shilito 1975）と考えられる，母ヤギと子ヤギを 生後 15 週齢調べた Robert（1984/1985）によると，母ヤ ギの発する低い音声は，子ヤギと結びつけるためのもの であり, 生後 4 日齢位までの子ヤギの音声には個体の行 動特性的な特徵は見られず，母ヤギにとっては，この期 間, 自分の子ヤギを識別するのに, 他の感覚器官の組み 合わせに依存しているとされている. 音声のレパート リーが, 10 個もの信号に及ぶときは, 親子間の関係が長 く続くという報告（Leroy 1983）もあり, 音声のレパート
リーが多いと母子関係が継続され，その機能が維持され ていくのに有利であると考えられる. 今回の母子間の相 互作用の 24 通りの組み合わせは, 3 週間内にすべて見ら れ，母子間の絆の継続を示唆していた。

今回のように，母子間距離が近距離にある羊舎内にお いても，母子双方に口の開閉による発声が見られ，また 発声のタイプによって反応のしかたが異なったことか ら，母子間において情報伝達の方法を発声タイプによっ て使い分けていることが示唆された。母ヒツジの発声に 応答する子ヒツジの音声は, 母ヒツジが子ヒツジをたや すく視認するのを助けるのかもしれないとする報告 


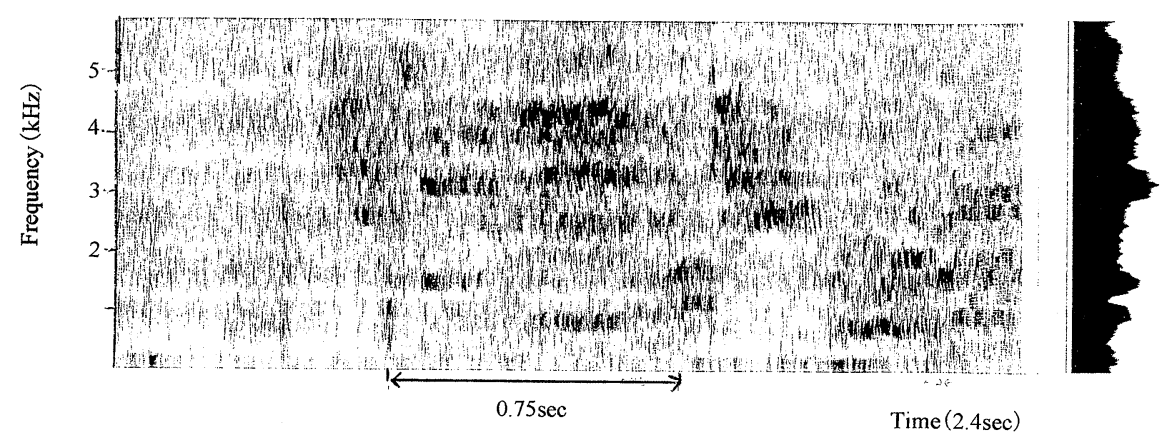

/nnn/
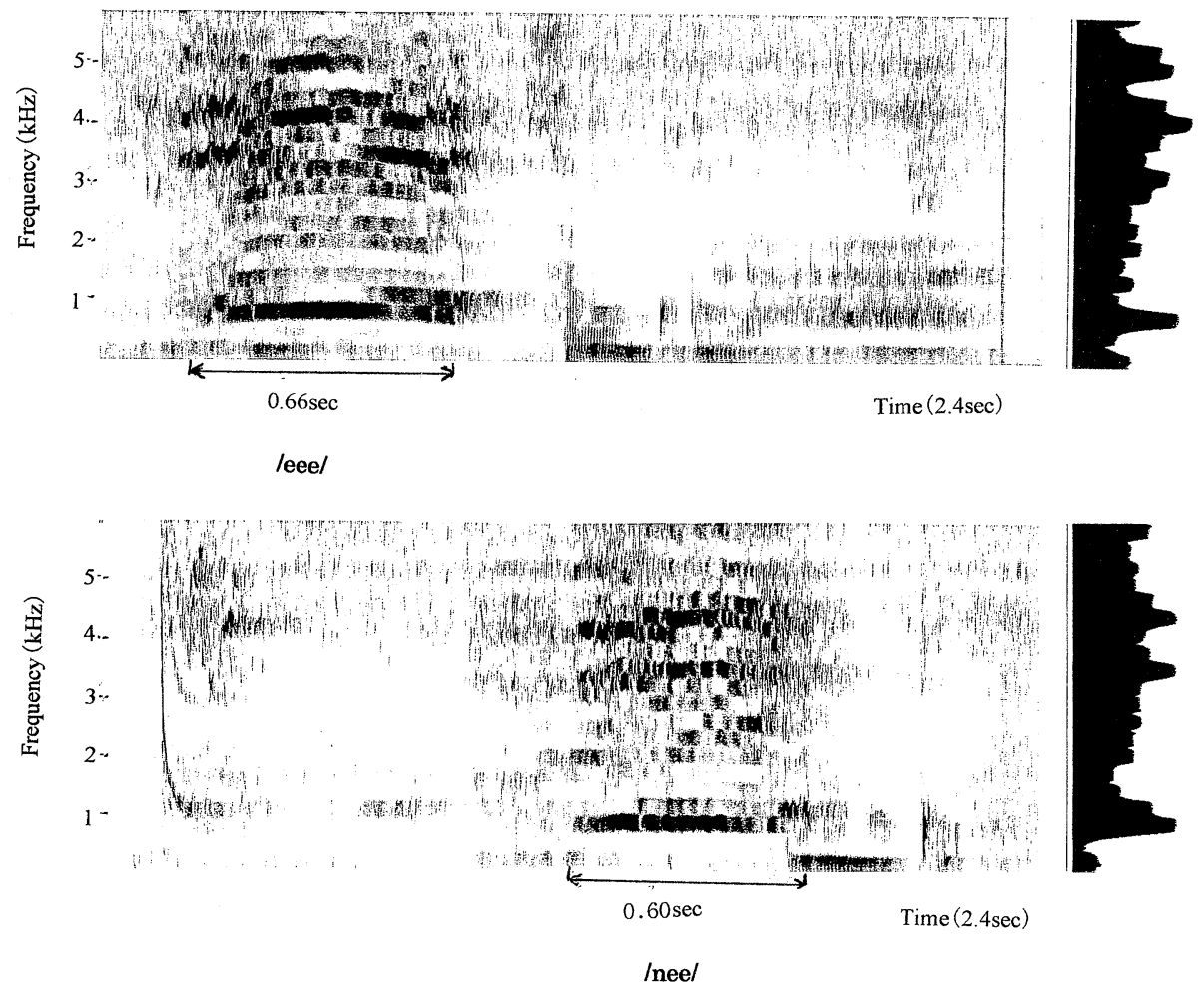

Fig. 3. Spectrogram of vocalization /nnn/, /eee/, /nee/ of lamb No. 2 initiative and section analysis (wide-band filter).

（Shllito 1975）があり，母ヒツジは子ヒツジの視認や授 乳のために音声で積極的に働きかけている一方，子ヒツ ジにとっては，母ヒツジから授乳される以外に絶えず吸 乳に結びつくための行動をしているものと考えられた.

ヒツジのコミュニケーションに情報理論を用いること で，母子ヒツジ間へ伝達される情報量を推測することが できた。すなわち情報量のビット数が多いほど，次に起 ることに関する受け手側の不確定度は大きく減少すると され，情報量が 0 ビットよりも大きいと，そこに何らか のコミュニケーションが起こっているかどうかを決定す ることができる (Halliday と Slater 1998). 今回の結果よ り，子ヒツジの情報量は母の情報量より大きい傾向にあ
り，母子ヒツジ間に共有される情報量が 0 ビットよりも 大きい傾向が示されたことから，小群内における母子間 の伝達には，双方の特定の情報量で伝達しあっているこ とが確認された。 また，母子ヒツジ間に共有される情報 量は 0 ビットよりも大きく，母子ヒツジ双方に情報の共 有があったことが示された。このことは，野外において 調査したモンゴルアルシャンツ・ブルト地区の夏営地に おけるヒツジ母子間の行動調査における報告（苗川ら 2002）において，母子間に共有される情報量が 0 ビッ卜 よりも大きく，双方には情報の共有があることが示され ていることとも一致した。

一方，音声による接近行動のイニシアチブは，生後 21 
Table 3. Verbal interaction initiated by the lamb

\begin{tabular}{|c|c|c|c|c|c|c|c|c|c|c|c|}
\hline & & \multirow[b]{2}{*}{ Type } & \multirow[b]{2}{*}{$/ \mathrm{nnn} /$} & \multirow[b]{2}{*}{ /nae/ } & \multirow[b]{2}{*}{ /nnae/ } & \multicolumn{5}{|c|}{ Ewe } & \multirow[b]{2}{*}{ Total } \\
\hline & & & & & & $\mathrm{A} 1$ & $\mathrm{~A} 2$ & A3 & $\mathrm{B} 1$ & B2 & \\
\hline & No 1 & $/ \mathrm{nnn} /$ & 0 & 0 & 4.8 & 14.2 & 9.5 & 9.5 & 0 & 0 & 38.0 \\
\hline & & /eee/ & 0 & 0 & 0 & 9.5 & 0 & 0 & 4.8 & 0 & 14.3 \\
\hline & & /nee/ & 0 & 0 & 4.8 & 33.3 & 0 & 4.8 & 4.8 & 0 & 47.7 \\
\hline & & Total & 0 & 0 & 9.6 & 57.0 & 9.5 & 14.3 & 9.6 & 0 & 100 \\
\hline & No $2^{*}$ & /nnn/ & 3.3 & 0 & 4.9 & 8.2 & 0 & 1.6 & 0 & 0 & 18.0 \\
\hline & & /eee/ & 0 & 0 & 1.6 & 0 & 0 & 1.6 & 0 & 0 & 3.2 \\
\hline & & /nee/ & 24.6 & 0 & 4.9 & 42.6 & 0 & 6.7 & 0 & 0 & 78.8 \\
\hline & & Total & 27.9 & 0 & 11.4 & 50.8 & 0 & 9.9 & 0 & 0 & 100 \\
\hline \multirow[t]{12}{*}{ Lamb } & No 3 & $/ \mathrm{nnn} /$ & 0 & 0 & 0 & 20.0 & 0 & 20.0 & 0 & 0 & 40.0 \\
\hline & & /eee/ & 0 & 0 & 0 & 20.0 & 0 & 0.0 & 0 & 0 & 20.0 \\
\hline & & /nee/ & 0 & 0 & 0 & 20.0 & 0 & 20.0 & 0 & 0 & 40.0 \\
\hline & & Total & 0 & 0 & 0 & 60.0 & 0 & 40.0 & 0 & 0 & 100 \\
\hline & No 4 & /nnn/ & 12.5 & 0 & 12.5 & 0 & 0 & 12.5 & 6.3 & 0 & 43.8 \\
\hline & & /eee/ & 0 & 0 & 6.3 & 0 & 0 & 0 & 0 & 0 & 6.3 \\
\hline & & /nee/ & 12.5 & 0 & 0 & 31.3 & 0 & 6.3 & 0 & 0 & 50.0 \\
\hline & & Total & 25 & 0 & 18.8 & 31.3 & 0 & 18.8 & 6.3 & 0 & 100 \\
\hline & No 5 & /nnn/ & 0 & 0 & 0 & 50.0 & 33.3 & 16.7 & 0 & 0 & 100 \\
\hline & & /eee/ & 0 & 0 & 0 & 0 & 0 & 0 & 0 & 0 & 0 \\
\hline & & /nee/ & 0 & 0 & 0 & 0 & 0 & 0 & 0 & 0 & 0 \\
\hline & & Total & 0 & 0 & 0 & 50.0 & 33.3 & 16.7 & 0 & 0 & 100 \\
\hline
\end{tabular}

Unit : (\%) Sample number : Ewe (Lamb) No $1: 22$ (21), No $2: 89$ (61), No $3: 150$ (5), No $4: 130$ (16), No 5 : 168 (6). /nnn/ : closed mouth, /nae/, /eee/ : open mouth, /nnae/, /nee/ : open mouth from closed mouth.

A1: No response. Eye contact from lamb. A2 : No response. Lamb approaching ewe.

A3 : No response. Lamb approaching ewe before suckling.

B1: No response. Ewe approaching lamb.

B2 : No response. Ewe approching lamb before nursing.

* Fisher's exact probability test, $P<0.05$.

日目までは，母ヒツジ主導型であることが示された。こ の接近行動のイニシアチブは, アカゲザルの研究では, 母と子が接触するうえでの母の役割が子の成長と共に減 少していくことを示す指数として使用されている（Martin と Bateson 1990) が, 今回の3 週間の母子間の観察結 果では，必ずしも減少せず，ヒツジにおける母子間の接 近行動のイニシアチブの多様性が示された。 また, 発声 をともなわない接近行動のイニシアチブは，子ヒツジの ほうが大きい傾向にあり, 母子間の接近行動のイニシア チブが子のほうに移ったのは生後 2 週間内であったヤギ での報告（Robert 1984/1985）に一致するものであった.

残された課題としては，2 号母ヒツジの例のように年 齢が高く出産歴が多い個体では, /nnn/の音声表記の夕 イプで情報伝達する傾向にあるのか，また作用個体の情 報量 $H(S)$ が反応個体の情報量 $H(R)$ より, 反応個体 の情報伝達の効率 TE（R）が作用個体の情報伝達の効率
TE（S）よりも大きくなるのかといったことについては, 今後, 例数を増やして検討していく必要があるものと考 えられる. また，2号子ヒツジのように生時体重の大き い個体では, 発声回数や吸乳回数も多くなるのかなどに ついても，母ヒツジの年齢や出産回数亡関連させて追究 していく必要がある.

以上のことから，生後3 週間におけるヒツジ母子間の 相互作用は, 情報伝達機能上, 口を開けた発声が主導を 占め, 発声後は相手を注視もしくは視認し, その後の行 動に移行する反応系で構成されていることが確認され た。その際には，母子間の情報量は，子ヒツジによって 利用されることが多く，母ヒツジの発声タイプによって 影響されることも示された. 子ヒツジの母ヒツジに対す る発声をともなう行動は, 吸乳にともなう栄養補給のた めの個体維持行動の機能のみならず，発声することに よって母子間の絆を維持しようとする世話要求行動の機 
Table 4. The index of ewes interaction to maintain proximity between itself and lamb

\begin{tabular}{|c|c|c|c|c|c|c|c|c|c|c|}
\hline \multirow[b]{2}{*}{ Ewe-Lamb No } & \multicolumn{5}{|c|}{ Vocal communication to maintain proximity } & \multicolumn{5}{|c|}{ Nonvocal communication to maintain proximity } \\
\hline & 1 & 2 & 3 & 4 & 5 & 1 & 2 & 3 & 4 & 5 \\
\hline \multirow{21}{*}{$\begin{array}{l}\text { Days after birth } \\
\\
\\
\\
1 \\
1 \\
1 \\
1 \\
1 \\
1 \\
1 \\
1 \\
1 \\
1 \\
2 \\
2\end{array}$} & - & - & - & - & - & 0 & - & - & - & - \\
\hline & 1 & - & 1 & - & - & - & - & - & - & - \\
\hline & 1 & 1 & 0 & 0.7 & 1 & 0.4 & 1 & - & 1 & - \\
\hline & 1 & - & 1 & 1 & 1 & 0 & 0 & 1 & 1 & 1 \\
\hline & - & 1 & 0 & 1 & 1 & 0 & -1 & 1 & - & -1 \\
\hline & - & 1 & 1 & 1 & 0 & 0 & 1 & 0.3 & - & -0.5 \\
\hline & - & 0.6 & 1 & 0.7 & 0.9 & 0 & 0.5 & -0.5 & 1 & -0.7 \\
\hline & 0.8 & 0.8 & 1 & 1 & 1 & 0.8 & 1 & 0 & -1 & -0.8 \\
\hline & - & 0 & 1 & 1 & 1 & 0 & 0.5 & 0 & -1 & -0.4 \\
\hline & 0.3 & 0.4 & 1 & 1 & 0.7 & -0.5 & 0 & 1 & -0.7 & -0.4 \\
\hline & 1 & 0 & -0.1 & 0.6 & 0.9 & -0.8 & 1 & -0.4 & -0.4 & -0.5 \\
\hline & 0.5 & 0.6 & 0 & 0.5 & 1 & 0.5 & 0.1 & 0.3 & 0 & 0.3 \\
\hline & 1 & 0.6 & 0.8 & 1 & 1 & -0.7 & -0.2 & 0.3 & -0.3 & -0.5 \\
\hline & 0.3 & 0 & 1 & 0.5 & 1 & -0.5 & 0 & 1 & 0 & 0 \\
\hline & 1 & 0.7 & 1 & 0 & 1 & -0.3 & 0.2 & -0.8 & 0.3 & -0.5 \\
\hline & 0 & 0.5 & 1 & 0 & 0.5 & 0 & -0.2 & -0.5 & 0 & 0 \\
\hline & 0 & 0.8 & 0.8 & 0.8 & 0 & -0.8 & -0.8 & -0.7 & -0.5 & -0.5 \\
\hline & 0 & 0.8 & - & 1 & 1 & 0 & 0.3 & - & 0 & -1 \\
\hline & 0 & 0.4 & - & 0.8 & - & -0.7 & 0.3 & - & -0.3 & - \\
\hline & - & 1 & - & -0.5 & - & - & 1 & - & - & - \\
\hline & - & 1 & - & - & - & - & 0.5 & - & - & - \\
\hline
\end{tabular}

Mean \pm SD $0.55 \pm 0.45^{A} \quad 0.61 \pm 0.350 .71 \pm 0.450 .66 \pm 0.430 .81 \pm 0.35^{\mathrm{B}}-0.15 \pm 0.45^{\mathrm{a}} 0.27 \pm 0.59^{\mathrm{b}} 0.15 \pm 0.66^{\mathrm{C}}-0.06 \pm$ $0.66-0.36 \pm 0.52^{\mathrm{d}}$

- : Not determined. Plus : initiated by ewe. Minus : initiated by lamb.

$A B, a b, a c:$ A significant difference in the same line (Repeated measure post-hoc test, $P<0.05$ ).

${ }_{b d, c d}$ : A significant difference in the same line (Repeated measure post-hoc test, $P<0.01$ ).

能をも併せ持っているものと考えられた。 また，母ヒツ ジにおいても，発声することで母子間の絆を維持しょう とする世話行動の機能を持つものと考えられた。

\section{文献}

Arnold GW. 1975. The role of sight and hearing in the lamb in the location and discrimination between ewes. Applied Animal Ethology, 1 : 167-176.

Alexander G, Boud CAP, Morgan PD, Bartle G. 1977. Role of auditory and visual cues in mutual recognition between ewes and lambs in merino sheep. Applied Animal Ethology, $3: 65-81$.

Bright M. 1986. 動物たちの話し声. 186-191. どうぶつ社.（熊 田清子訳)，東京.

Collias NE. 1956. The analysis of socialization in sheep and goats. Ecology, 37-2 : 228-239.

Hafez ESE. 1992. 家畜繁殖学第 5 版. （吉田重雄・正木淳二 ・ 入谷 明訳), 284-288. 西村書店. 新潟.

Halliday TR, Slater PJB. 1998. 動物コミュニケーション. 第一
刷. (浅野俊夫・長谷川芳典・藤田和生訳)，197-363. 西村 書店. 新潟.

Harold CW. 1963. The auditory acuity of the sheep. The journal of Auditory Research, $3: 121-132$.

Houpt W. 1982. Domestic animal behavior for veterinarian and animal scientists. Domestic animal behavior, cattle, sheep, and goats. Auditory and visual, 1: 23-24.

Hulet CV, Alexavder G, Hafez ESE. 1976. The behaviour of domestic animals, Chapter II, The behabiour of sheep, 284286.

粕谷英一・藤田和幸. 1984. 動物行動学のための統計学, 第一 刷. (伊藤嘉昭監修), 84-93. 東海大学出版会. 東京.

Kent RD, Read C. 1996. 音声の音響分析. 第一刷. (荒井隆行 · 菅原 勉監訳)，6-251. 海文堂. 東京.

Kiley M. 1972. The vocalization of ungulates, their causion and function. Zeitschrift fur Tierpsychologie, 31: 171-222.

Leroy Y. 1983. 動物の音声の世界. 第一刷.（稲垣 新・番場州 一訳), 138. 共立出版. 東京.

Martin P, Bateson P. 1990. 行動研究入門. 第一刷. (粕谷英一 近 雅博. 細馬宏道訳)，100-101. 東海大学出版会. 東京. 


\section{ヒツジ母子間の接近の維持}

Morgan PD, Arnold GW. 1974. Behavioural relationships between merino ewes and lambs during the four weeks after birth. Animal Production, 19: 169-176.

苗川博史・Buyan B・Myakhdadag B. 2002. モンゴルアルシャ ンツ・ブルト地区の夏営地におけるヒツジ母子間の行動調 査. 在来家畜研究会報告, $20: 65-77$.

Poindron P, Carrick MJ. 1976. Hearing recognition of the lamb by its mother. Animal Behavior, 24 : 600-602.

Robert EL. 1984/1985. Mother-infant spatial relationships in domestic goats. Appllied Animal Behavior Science, 13 : 93100.

柴谷方良・影山太郎・田守育啓. 1982. 言語の構造 理論と分 析 音声. 音韻篇. 第2 刷. 11-91. くろしお出版. 東京.
Shillito EE. 1972. Vocalization in sheep. Journal of Physiology, Proceedings of the Physiological Society, 226 : 45-46.

Shillito E, Alexander G. 1975. Mutual recognition amongst ewes and lambs of four breeds of sheep. Applied Animal Ethology, 1: 151-165.

Shillito EE. 1975. A comparison of the role of vision and herring in lambs finding their own dams. Applied Animal Ethology, 1 : 369-377.

Walser SE, Walters E, Hague P. 1982. Vocal communication between ewes and their own and alien lambs. Behavior, 81 : 140-151.

Wilson EO. 1984. 社会生物学. (吳 漉盡 - 嚴佐 庸 - 北村省 -・前川幸恵訳, 伊藤嘉昭監修)，425，思索社. 東京. 
苗川

\title{
Approximating Initiative and its Changes Influenced by Vocalized Communication between Ewes and Lambs during a Period of Three Weeks after Birth
}

\begin{abstract}
Hirofumi NAEKAWA
Senior High School attached to Shonan Instituted of Technology, Fujisawa-shi 251-8511, Japan

Corresponding : Hirofumi Naekawa (fax : +81 (0) 467-54-5328, e-mail : naekawa@beige.plala.or.jp)

Using five pairs of ewes and lambs in a small flock comprising 14 or 20 sheep, the ewe-lamb reaction (hereafter referred to as "interaction") in the form of vocalized communication was studied for a period of three weeks after birth based on phonetic notations and information volume, and the day-to-day changes in the ewe-lamb approximating behavior were analyzed. With regard to the phonetic notations, from the standpoint of articulation action, we identified the sounds of /nnn/, /nae/ and /nnae/ by ewes and /nnn/, /eee/ and /nee/ by lambs. All these sounds were produced by opening or closing the mouth as utterance patterns. As for the interaction, we analyzed 24 different dyadic interactions based on 3 types of utterance for ewes and lambs respectively and 8 types of subsequent reactions (utterance by either ewe or lamb followed by action of the other or both is considered a completed action of the pair), as well as the volume of information contained in such activities. To study the approximating behavior, sheep were individually analyzed on a daily basis by discriminating between involvement and non-involvement of utterance. The results showed that the ewe-lamb interaction was led by opened-mouth utterance as a communicative function, which was followed by reactions comprising visual recognition or gaze and subsequent action. An individual specificity was observed in the reaction caused according to the type of mouth opening and closing, and the reaction differed depending on the way of utterance. In any type of utterance pattern, the information volume shared by ewes and lambs was greater than 0 bit, demonstrating the involvement of information sharing between ewes and lambs. With regard to the results of phonetic notations, differences were observed in the frequency and duration depending on the type of utterance, which enabled us to demonstrate features of respective utterance structures. To be more specific, the opened-mouth /nae/ and /nnae/ in ewes recorded a frequency $50 \mathrm{~Hz}$ higher than that for the closed-mouth /nnn/, and the former utterance pattern tended to last longer than the latter by 0.1 second. In the case of lambs, the openedmouth /eee/ and /nee/ also showed a frequency $50 \mathrm{~Hz}$ higher than that for the closed-mouth /nnn/. However, the duration of the former utterance patterns tended to be shorter by 0.1 to 0.2 second. Although the ewes demonstrated the initiative in showing an utterance-based approximating behavior towards lambs during the three weeks after birth, the lambs showed a greater tendency to initiate approximating behavior not involving utterance.
\end{abstract}

Nihon Chikusan Gakkaiho, 75 (2) : 228-239, 2004

Key words : Sheep, Vocalization, Communication, Phonetic sign, Proximity 